\title{
Desain Optimal Power System Stabilizer Pada System Kelistrikan Sulselrabar Menggunakan Bat Algorithm
}

\author{
Muhammad Ruswandi Djalal ${ }^{1}$, Faisal $^{2}$
}

\begin{abstract}
The problem of using Power System Stabilizer (PSS) in generator excitation is how to determine the optimal PSS parameter. To overcome these problems, the authors use a method of intelligent bats based algorithm to design PSS. Bat Algorithm is an algorithm that works based on bat behavior in search of food source. Correlation with this research is, food sources sought by bats represent the parameters of PSS to be optimized. Bat's algorithm will work based on a defined destination function, namely Integral Time Absolute Error (ITAE). In this research will be seen the deviation of velocity and rotor angle of each generator, in case of disturbance in Bakaru generator. The results show that the uncontrolled system produces large overshoot oscillations, and after the addition of PSS oscillation control equipment can be muted. So that the overshoot and settling time of each generator can be reduced and the generator can quickly go to steady state condition.
\end{abstract}

Intisari--Masalah penggunaan Power System Stabilizer (PSS) pada eksitasi generator adalah bagaimana menentukan parameter PSS yang optimal. Untuk mengatasi masalah tersebut, penulis menggunakan metode cerdas berbasis algoritma kelelawar untuk mendesain PSS. Algoritma Kelelawar adalah algoritma yang bekerja berdasarkan perilaku kelelawar dalam mencari sumber makanan. Korelasi dengan penelitian ini adalah, sumber makanan yang dicari oleh kelelawar merepresentasikan sebagai parameter PSS yang akan dioptimasi. Algoritma kelelawar akan bekerja berdasarkan fungsi tujuan yang sudah ditentukan, yaitu Integral Time Absolute Error (ITAE). Pada penelitian ini akan dilihat respon deviasi kecepatan dan sudut rotor setiap generator, bila terjadi gangguan di Bakaru generator. Hasil analisa menunjukkan, sistem tanpa kontrol menghasilkan osilasi overshoot yang besar, dan setelah tambahan peralatan kontrol PSS osilasi tersebut dapat diredam. Sehingga overshoot dan settling time masing masing generator dapat dikurangi dan generator dapat dengan cepat menuju ke kondisi steady state.

Kata Kunci : Power System Stabilizer, Algoritma Kelelawar, Speed, Overshoot, Settling Time.

\section{PENDAhUluan}

Sebagian besar sistem tenaga listrik fungsi pengontrolnya ada pada governor dan eksiter pada masing-masing generator. Namun, keterbatasan kinerja peralatan control tersebut, menyebabkan generator tidak dapat bekerja dengan optimal. Power System Stabilizer (PSS) kontroller tambahan juga

${ }^{1}$ Dosen Teknik Energi Program Studi Teknik Energi, Politeknik Negeri Ujung Pandang, Jalan Perintis Kemerdekaan 10, Makassar 90245, Indonesia

E-mail : ${ }^{1}$ wandi@poliupg.ac.id

${ }^{2}$ Staf Teknik Energi Program Studi Teknik Energi, Politeknik Negeri Ujung Pandang, Jalan Perintis Kemerdekaan 10, Makassar 90245, Indonesia

E-mail : ${ }^{2}$ faisall@poliupg.ac.id ditambahkan pada pengatur tegangan otomatis (AVR), fungsi dari eksiter, governor dan PSS adalah mengatur frekuensi dan tegangan terminal secara lokal atau global pada masingmasing generator. Perubahan beban yang terjadi secara tibatiba dan periodik tidak dapat direspon dengan baik oleh generator sehingga dapat mempengaruhi kestabilan dinamik sistem. Respon yang kurang baik dapat menimbulkan osilasi frekuensi dalam periode yang lama. Hal itu dapat mengakibatkan pengurangan kekuatan transfer daya yang dapat diatasi menggunakan peralatan tambahan yang disebut PSS.

Kestabilan dari sistem tenaga listrik yang ada, umumnya terdiri dari kestabilan steady state dan kestabilan transient. Kestabilan transient dikaitkan dengan gangguan besar yang tiba-tiba terjadi, misalkan seperti gangguan hubung singkat, pemutusan saluran, pemindahan atau pemutusan beban pada sistem. Sedangkan untuk kestabilan steady state berhubungan dengan kemampuan sistem tenaga listrik untuk kembali pada operating point-nya setelah gangguan kecil terjadi. Parameter sistem dikatakan stabil apabila seluruh variable keadaannya stabil, frekuensi sistem, tegangan bus, atau sudut generator. Sedangkan parameter untuk ketidakstabilan pada sistem seperti tegangan pada beberapa bus turun drastis jauh dari kondisi normal sehingga memungkinkan terjadi gagal tegangan.

Selain studi tentang kestabilan system tenaga yang menjadi hal yang penting, studi lain seperti peramalan beban [1] dan penjadwalan pembangkit [2], juga menjadi bagian yang penting dalam perkembangan sistem. Sistem Sulawesi Selatan, Tenggara dan Barat (Sulselrabar) merupakan system kelistrikan yang menghubungkan beberapa pusat beban dengan tegangan operasi $150 \mathrm{kV}$. Diperlukan beberapa studi system kelistrikan di Sulselrabar, seiring meningkatnya system di sulselrabar. Beberapa penelitian telah dilakukan untuk system Sulselrabar, diantaranya [3], [4], [5]. Studi Kestabilan system tenaga listrik merupakan hal yang penting untuk menjaga keandalan system. Metode kecerdasan buatan merupakan salah satu metode yang banyak digunakan pada system tenaga listrik. Pada studi kestabilan system tenaga di system sulselrabar, aplikasi metode cerdas sudah mulai dilakukan. Metode cerdas berbasis Algoritma Kelelawar merupakan algoritma yang bekerja berdasarkan perilaku kelelawar dalam mencari makanan. Korelasi dengan penelitian ini adalah Bat Algorithm akan mencari parameter optimal dari PSS dengan menggunakan objective function yang sudah ditentukan, yaitu meminimalkan Integral Time Absolute Error (ITAE). Beberapa penelitian berbasis metode cerdas untuk penalaan diantaranya, firefly [6], Particle Swarm Optimization [7], Genetic Algorithm [8], Neural Network [9], Fuzzy Logic [10], Ant Colony [11], Bee Colony [12], Cuckoo Search [13]. Oleh karena itu pada penelitian ini akan diusulkan metode cerdas berbasis Bat Algorithm untuk 
mendesain PSS pada system Sulselrabar, yang selama ini belum digunakan pada generator system Sulselrabar.

\section{STUDI LITERATUR}

\section{A. Pemodelan Generator Sinkron}

Pemodelan liniear generator sinkron diperlukan untuk menganalisa efek dari perubahan daya terhadap respon frekuensi maupun sudut rotor. Dengan menggunakan Transformasi Park maka generator sinkron dapat dimodelkan kedalam persamaan matematis dan dilinearisasi pada Persamaan 1 .

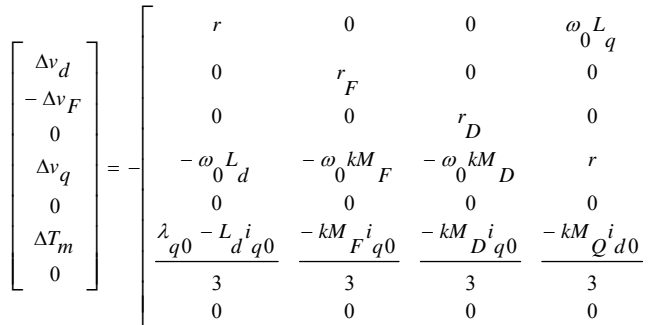

$$
\begin{aligned}
& \left.\begin{array}{ccc}
\omega_{0} k M_{Q} & \lambda_{q 0} & 0 \\
0 & 0 & 0 \\
0 & 0 & 0 \\
0 & -\lambda_{d 0} & 0 \\
r_{Q} & 0 & 0 \\
\frac{k M_{Q^{i} d 0}}{3} & -D & 0 \\
0 & -1 & 0
\end{array}\right]\left[\begin{array}{c}
\Delta i_{d} \\
\Delta i_{F} \\
\Delta i_{D} \\
\Delta i_{q} \\
\Delta i_{Q} \\
\Delta \omega \\
\Delta \delta
\end{array}\right] \\
& -\left[\begin{array}{ccccccc}
L_{d} & k M_{F} & k M_{D} & 0 & 0 & 0 & 0 \\
k M_{F} & L_{F} & M_{R} & 0 & 0 & 0 & 0 \\
k M_{D} & M_{R} & L_{D} & 0 & 0 & 0 & 0 \\
0 & 0 & 0 & L_{q} & k M_{Q} & 0 & 0 \\
0 & 0 & 0 & k M_{Q} & L_{Q} & 0 & 0 \\
0 & 0 & 0 & 0 & 0 & -\tau_{j} & 0 \\
0 & 0 & 0 & 0 & 0 & 0 & 1
\end{array}\right]\left[\begin{array}{c}
\Delta \dot{i}_{d} \\
\Delta \dot{i}_{F} \\
\Delta \dot{i}_{D} \\
\Delta \dot{i}_{q} \\
\Delta \dot{i}_{Q} \\
\Delta \dot{\omega} \\
\Delta \dot{\delta}
\end{array}\right]
\end{aligned}
$$

\section{B. Pemodelan Exciter}

Peralatan eksitasi merupakan suatu bagian dari sistem yang berfungsi untuk mengatur variabel output generator, misal tegangan, arus, dan faktor daya. Variabel ini akan diatur melalui perubahan fluks medan pada generator. Diagram blok dari exciter ditampilkan pada Gambar 1 berikut.

Gambar 1. Diagram Blok Exciter

\section{Pemodelan Governor}

Governor merupakan pengendali yang berfungsi untuk mengatur nilai torsi mekanik $T_{m}$ yang menjadi masukan dari generator. Governor pada PLTA mengatur besar ketinggian katup yang mempengaruhi aliran air dari pipa air menuju Muhammad Ruswandi Djalal: Desain Optimal Power System... turbin air. Sedangkan pada PLTU governor berperan untuk mengatur ketinggian katup yang mempengaruhi semburan uap dari ketel uap. Berikut bentuk diagram blok dari Governor.

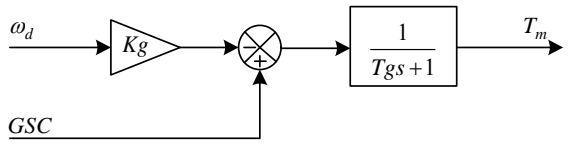

Gambar 2. Diagram Blok Governor

\section{Pemodelan Power System Stabillizer}

PSS digunakan untuk menghasilkan komponen redaman tambahan dengan memproduksi torsi elektris yang sesuai dengan deviasi pada kecepatan rotor. Metode desain PSS secara umum melibatkan frekuensi respon yang berdasarkan pada konsep peningkatan redaman torsi. Blok diagram dari PSS terdapat pada Gambar 3 [14].

Gambar 3. Diagram Blok PSS

\section{Algoritma Kelelawar}

Langkah utama dari BA adalah dimulai dari inisialisasi populasi sekumpulan kelelawar yang masing masing ditentukan oleh posisi awal sebagai solusi awal. Populasi sekumpulan kelelawar membangkitkan pulsa dan kebisingan secara acak serta menentukan frekuensi. Selama proses berulang/looping kelelawar akan bergerak dari solusi awal menuju solusi terbaik. Setelah pindah, jika ada kelelawar menemukan solusi yang lebih baik, maka kelelawar akan memperbarui tingkat pancaran pulsa dan kebisingan. Selama proses iterasi solusi terbaik selalu diperbarui. Proses iterasi diulang sampai kriteria berhenti dan kriteria solusi terbaik telah terpenuhi. Solusi terbaik adalah solusi bagi permasalahan yang diselesaikan oleh melalui proses algoritma ini. Parameter Bat Algorithm yang digunakan ditunjukkan pada table berikut. Prinsip kerja Bat adalah mengoptimisasi parameter dari PSS dalam suatu batasan yang telah ditetapkan. Parameter Bat ditampilkan pada Tabel berikut. Parameter PSS yang ditala adalah $\mathrm{K}_{\mathrm{PSS}}, \mathrm{T}_{1}, \mathrm{~T}_{2}, \mathrm{~T}_{3}$ dan $\mathrm{T}_{4}$. Nilai $\mathrm{T}_{\mathrm{W}}$ memiliki nilai dalam rank batasan $1-50$ detik, dalam penelitian $T_{W}$ ditetapkan konstan yaitu 10 detik. Berikut ini tabel parameter Bat dan PSS yang telah ditetapkan.

TABEL 1.

PARAMETER AlgoritMa BAT

\begin{tabular}{|c|c|}
\hline Parameter & Nilai \\
\hline Ukuran Populasi & 35 \\
\hline Kebisingan / Loudness & 0,25 \\
\hline Pulse Rate & 0,5 \\
\hline Alpha & 0,7 \\
\hline Gamma & 0,7 \\
\hline Frekuensi Minimum & 0 \\
\hline Frekuensi Maksimum & 100 \\
\hline Iterasi & 50 \\
\hline Dimensi & 80 \\
\hline
\end{tabular}

p-ISSN:1693 - 2951; e-ISSN: 2503-2372 
TABEL 2.

BATASAN NILAI PARAMETER PSS

\begin{tabular}{|c|c|c|c|}
\hline No & Parameter & Lower Limit & Upper Limit \\
\hline 1 & $\mathrm{~K}_{\mathrm{pss}}$ & 10 & 50 \\
\hline 2 & $\mathrm{~T}_{1}$ & 0 & 0.1 \\
\hline 3 & $\mathrm{~T}_{2}$ & 0 & 0.1 \\
\hline 4 & $\mathrm{~T}_{3}$ & 0 & 5 \\
\hline 5 & $\mathrm{~T}_{4}$ & 0 & 5 \\
\hline
\end{tabular}

untuk parameter Tw diset pada nilai 10 .

\section{OPTIMASI POWER SYSTEM STABILIZER MENGGUNAKAN BAT AlgORITHM}

Nilai Damping ratio $\xi$ dituliskan pada persamaan berikut

$$
\begin{gathered}
\xi_{i}=\frac{-\sigma_{i}}{\sqrt{\sigma_{i}^{2}+\omega_{i}^{2}}} \\
C D I=\sum_{i=1}^{n}\left(1-\xi_{i}\right)
\end{gathered}
$$

Melalui hasil eigenvalue persamaan 2, Performansi system dapat diamati dengan melihat Comprehensive Damping Index (CDI) pada persamaan 3. Algoritma Bat yang didesain pada penelitian ini akan bekerja berdasarkan fungsi tujuan (Objective Function) yang digunakan, di mana dalam penelitian ini Bat akan mencari nilai CDI yang paling minimum.

\section{HASIL DAN PEMBAHASAN}

Sistem kelistrikan Sulselrabar terdiri dari 16 unit pembangkit, yang beroperasi pada tegangan $150 \mathrm{kV}$, serta terdiri dari 37 Bus dan 46 saluran yang menghubungkan pusat-pusat beban besar seperti, Makassar, Pangkep, Maros, Barru, Pare-Pare, Pinrang, Polmas, Majene dan Mamuju. Fungsi tujuan (Objective Function) yang digunakan adalah memaksimalkan damping minimum $\left(\zeta_{\min }\right)$.

Selanjutnya dianalisa respon sistem yaitu Deviasi Kecepatan $(\Delta \omega)$ dan sudut rotor masing-masing generator. Selain itu juga akan dianalisis nilai overshoot dari masing masing generator untuks system tanpa control dan dengan PSS. Pemodelan linier sistem diberikan input gangguan perubahan permintaan beban sebesar 0.05 pu pada Generator Slack PLTA Bakaru. Karena perubahan beban ini, mengakibatkan perubahan di sisi beban menyebabkan $\mathrm{Pm}<$ Pe, sehingga $\omega$ dan $\delta$ generator akan turun.

$$
M \dot{W}=P_{m}-P_{e}-D \omega
$$

\section{A. Aliran Daya}

Gambar 4 menunjukkan flowchart bat gorithm. Setelah membuat pemodelan system sulselrabar dan memasukkan data-data system, maka selanjutnya akan dilakukan studi aliran daya untuk mengetahui profil magnitude dan sudut fasa masing-masing bus, hasilnya ditampilkan pada tabel berikut.

\section{B. Konvergensi Algoritma Kelelawar}

Berikut hasil konvergensi pencarian parameter PSS dengan algoritma kelelawar. Di mana terlihat dari grafik, algoritma sangat cepat dalam menemukan nilai optimal dari PSS dengan menggunakan metode algoritma kelelawar. Nilai fitness function yaitu sebesar 75.8423783057539 .
TABEL 3

MAGNITUDE DAN SUDUT TEGANGAN

\begin{tabular}{cccccc}
$\begin{array}{c}\text { No } \\
\text { Bus }\end{array}$ & $\begin{array}{c}\text { Tegangan } \\
\text { (p.u) }\end{array}$ & Sudut $\left.\mathbf{(}^{\mathbf{0}}\right)$ & $\begin{array}{c}\text { No } \\
\text { Bus }\end{array}$ & $\begin{array}{c}\text { Tegangan } \\
\text { (p.u) }\end{array}$ & Sudut $\left.\mathbf{(}^{\mathbf{0}}\right)$ \\
\hline 1 & 1,000 & 0.000 & 20 & 0,979 & -16.450 \\
2 & 1,000 & -3.869 & 21 & 0,983 & -18.428 \\
3 & 1,000 & -5.124 & 22 & 0,987 & -21.176 \\
4 & 1,000 & -4.041 & 23 & 0,960 & -23.033 \\
5 & 1,000 & -9.839 & 24 & 0,993 & -20.956 \\
6 & 1,000 & -20.793 & 25 & 0,994 & -19.485 \\
7 & 1,000 & -21.192 & 26 & 0,994 & -18.453 \\
8 & 1,000 & -20.221 & 27 & 0,990 & -8.949 \\
9 & 1,000 & -16.359 & 28 & 0,992 & -4.600 \\
10 & 1,000 & -13.152 & 29 & 0,992 & -17.723 \\
11 & 1,000 & -11.792 & 30 & 0,960 & -16.091 \\
12 & 1,000 & -2.500 & 31 & 0,933 & -17.110 \\
13 & 1,000 & 2.915 & 32 & 0,980 & -21.261 \\
14 & 1,000 & -11.380 & 33 & 0,984 & -21.251 \\
15 & 1,000 & -13.389 & 34 & 0,993 & -20.728 \\
16 & 1,000 & -20.966 & 35 & 0,996 & -20.760 \\
17 & 0,992 & -3.072 & 36 & 0,996 & -20.760 \\
18 & 0,974 & -5.217 & 37 & 0,975 & -22.476 \\
19 & 0,965 & -6.386 & & & \\
& & & & &
\end{tabular}

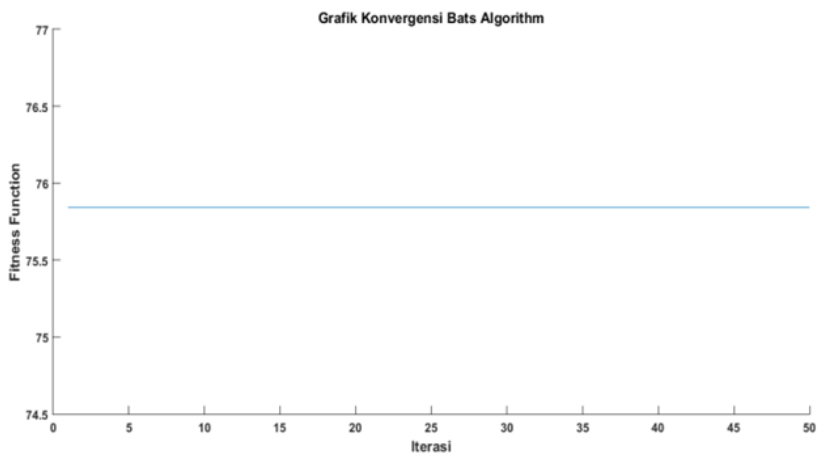

Gambar 5. Grafik Konvergensi Algoritma Kelelawar

TABEL 4. HASIL OPTIMASI PARAMETER PSS

\begin{tabular}{cccccc}
\hline Place & Kpss & T1 & T2 & T3 & T4 \\
\hline G1 & 38.6483 & 0.0243 & 0.0277 & 0.7740 & 1.8598 \\
G2 & 17.4338 & 0.0153 & 0.0109 & 0.7200 & 0.7924 \\
G3 & 25.4147 & 0.0199 & 0.0385 & 0.6569 & 0.9760 \\
G4 & 39.4503 & 0.0266 & 0.0117 & 0.6089 & 0.8877 \\
G5 & 44.0828 & 0.0284 & 0.0146 & 0.7818 & 1.2816 \\
G6 & 22.7142 & 0.0121 & 0.0200 & 0.1736 & 1.5760 \\
G7 & 43.2428 & 0.0169 & 0.0292 & 0.3854 & 0.3583 \\
G8 & 24.2463 & 0.0247 & 0.0256 & 0.4864 & 1.2950 \\
G9 & 23.6196 & 0.0183 & 0.0389 & 0.6131 & 1.0097 \\
G10 & 38.4322 & 0.0240 & 0.0104 & 0.4420 & 1.1055 \\
G11 & 26.9241 & 0.0174 & 0.0300 & 0.5450 & 1.4509 \\
G12 & 22.9460 & 0.0335 & 0.0223 & 0.5855 & 0.5511 \\
G13 & 41.4692 & 0.0131 & 0.0118 & 0.5147 & 1.4662 \\
G14 & 34.2208 & 0.0125 & 0.0213 & 0.3378 & 1.1100 \\
G15 & 32.0660 & 0.0155 & 0.0292 & 0.5649 & 0.3631 \\
G16 & 35.8701 & 0.0192 & 0.0160 & 0.3487 & 0.7889 \\
\hline
\end{tabular}

Pemasangan PSS dilakukan pada Generator Bakaru, Pinrang, Pare - Pare, Suppa, Barru, Tello, Tello lama, Sungguminasa, Bulukumba, Sinjai, Soppeng, Sengkang, Makale, dan Palopo. 


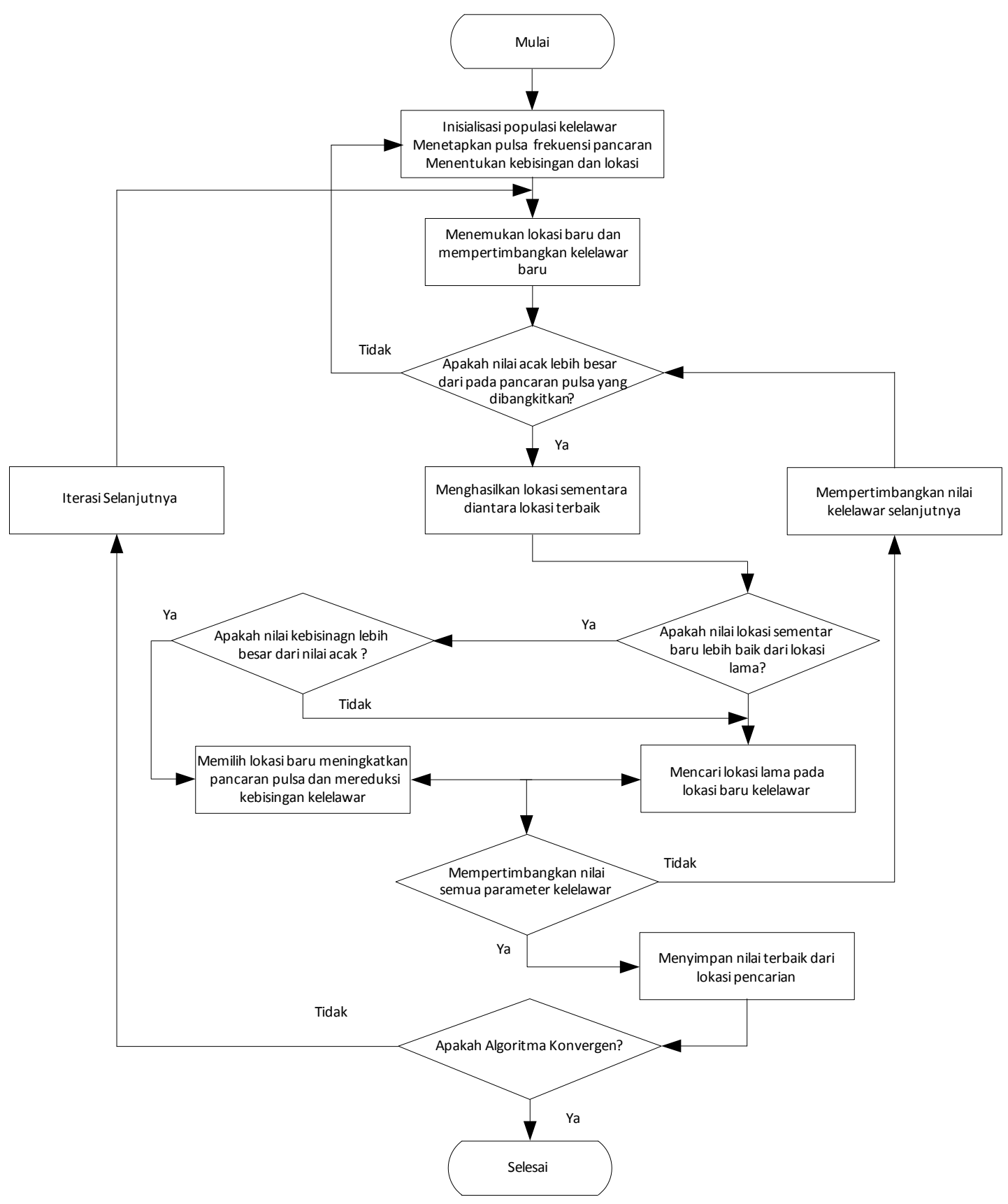

Gambar 4. Flowchart Bat Algorithm [15]

\section{Analisis dan Pembahasan}

Setelah dilakukan penempatan dan penalaan PSS dengan 14 lokasi penempatan PSS, selanjutnya melihat respon Deviasi Kecepatan $(\Delta \omega)$ dan sudut rotor dari setiap generator. Overshoot Deviasi Kecepatan dari generator akan dianalisisa perbedaannya. Tabel 5 menunjukkan

Muhammad Ruswandi Djalal: Desain Optimal Power System... perbandingan overshoot deviasi kecepatan masing-masing generator.

TABEL 5.

OVERSHOOT DEVIASI KECEPATAN GENERATOR

\begin{tabular}{ccc}
\hline Generator & No PSS & PSS Bat \\
\hline Bakaru & $-0.02563 \& 0.004704$ & $-0.01598 \& 9.635 \mathrm{e}-05$ \\
Pinrang & $-0.02385 \& 0.006865$ & $-0.01595 \& 0.0002214$ \\
Pare & $-0.02424 \& 0.004796$ & $-0.01638 \& 0.0001162$ \\
Suppa & $-0.02437 \& 0.006517$ & $-0.01435 \& 3.279 \mathrm{e}-05$ \\
\hline
\end{tabular}

p-ISSN:1693 - 2951; e-ISSN: 2503-2372 


\begin{tabular}{ccc}
\hline Barru & $-0.08467 \& 0.03666$ & $-0.03627 \& 0.0001224$ \\
Tello & $-0.2119 \& 0.05488$ & $-0.2027 \& 0.04589$ \\
Tello lama & $-0.2227 \& 0.09127$ & $-0.07708 \& 0.000385$ \\
Sgmnsa & $-0.05721 \& 0.007811$ & $-0.03956 \& 3.942 \mathrm{e}-05$ \\
Jeneponto & $-0.02519 \& 0.006135$ & $-0.01823 \& 0.0003905$ \\
Bulukumba & $-0.02447 \& 0.01018$ & $-0.01709 \& 0.00227$ \\
Sinjai & $-0.0263 \& 0.01804$ & $-0.01887 \& 0.006823$ \\
Soppeng & $-0.0248 \& 0.01153$ & $-0.01627 \& 0.001527$ \\
Sengkang & $-0.02694 \& 0.005042$ & $-0.01689 \& 0.0002121$ \\
Makale & $-0.02397 \& 0.01706$ & $-0.01573 \& 0.003737$ \\
Palopo & $-0.02442 \& 0.01894$ & $-0.01528 \& 0.004266$ \\
Borongloe & $-0.06846 \& 0.01621$ & $-0.04373 \& 4.929 \mathrm{e}-05$ \\
\hline
\end{tabular}

Gambar berikut menunjukkan respon Deviasi Kecepatan $(\Delta \omega)$ dan Variasi dari sudut rotor masing-masing generator.

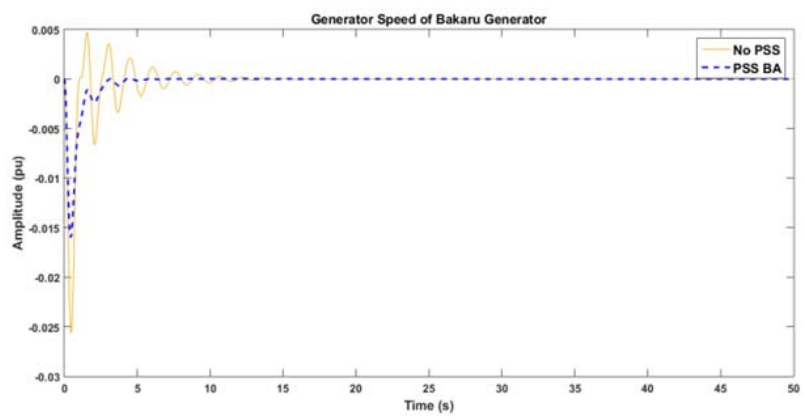

Gambar 6. Deviasi Kecepatan $(\Delta \omega)$ G. Bakaru

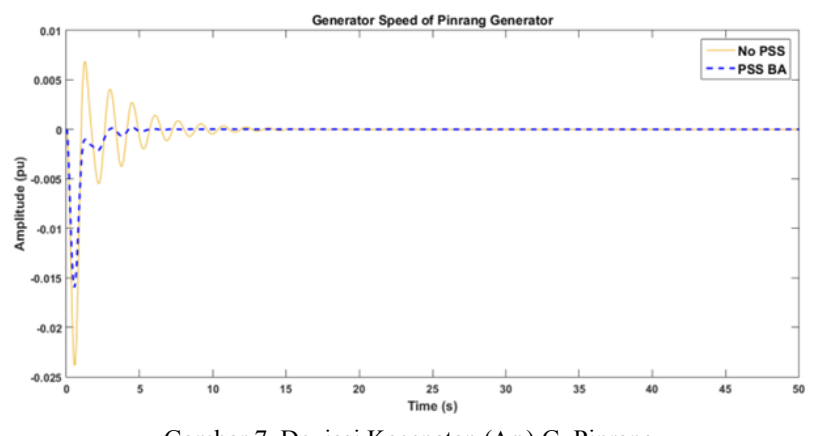

Gambar 7. Deviasi Kecepatan $(\Delta \omega)$ G. Pinrang

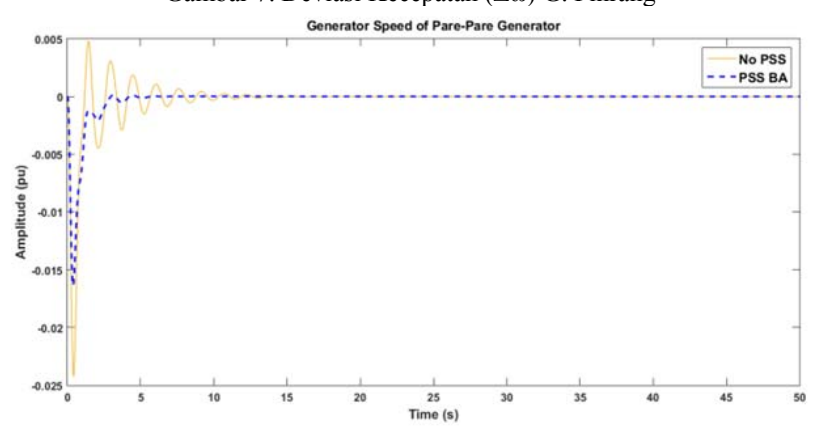

Gambar 8. Deviasi Kecepatan $(\Delta \omega)$ G. Pare

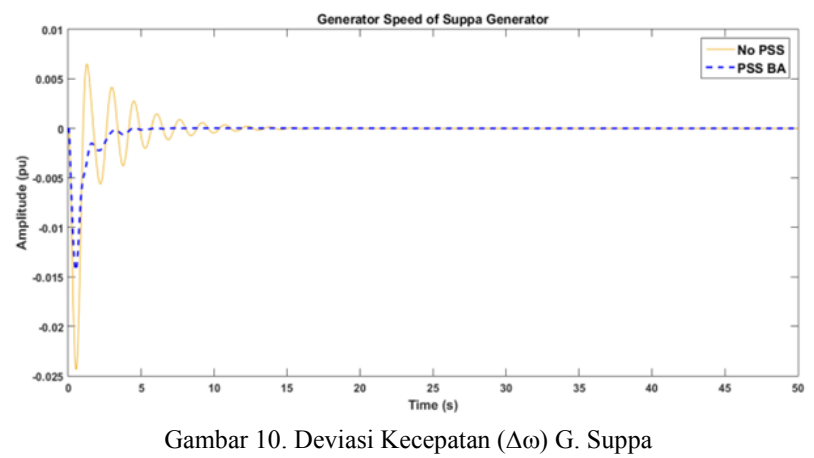

ISSN $1693-2951$

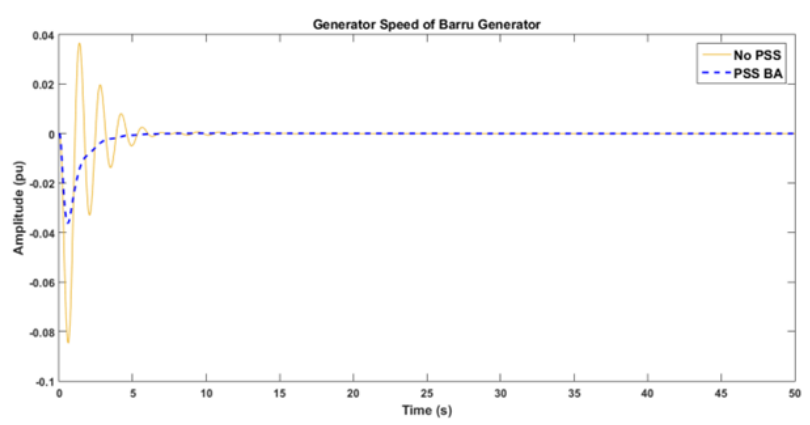

Gambar 11. Deviasi Kecepatan $(\Delta \omega)$ G. Barru

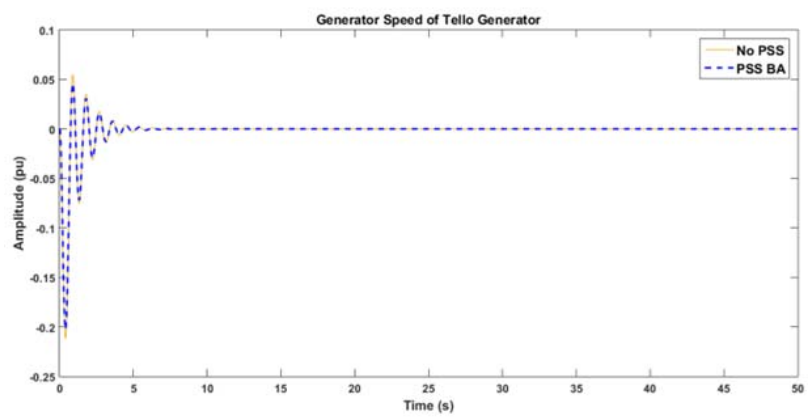

Gambar 12. Deviasi Kecepatan $(\Delta \omega)$ G. Tello

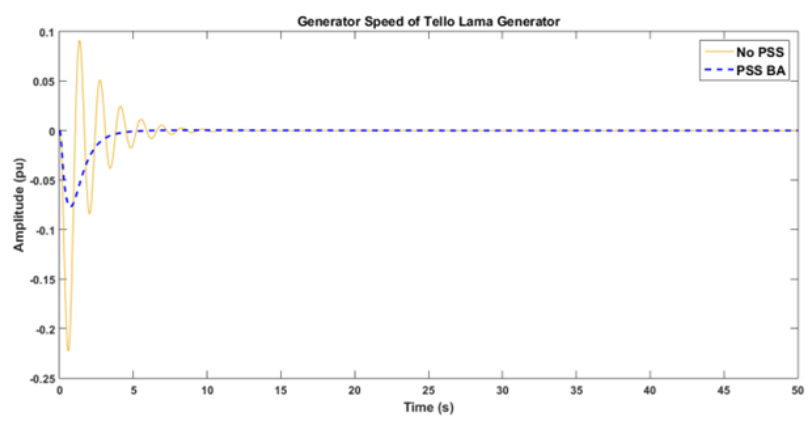

Gambar 13. Deviasi Kecepatan $(\Delta \omega)$ G. T Lama

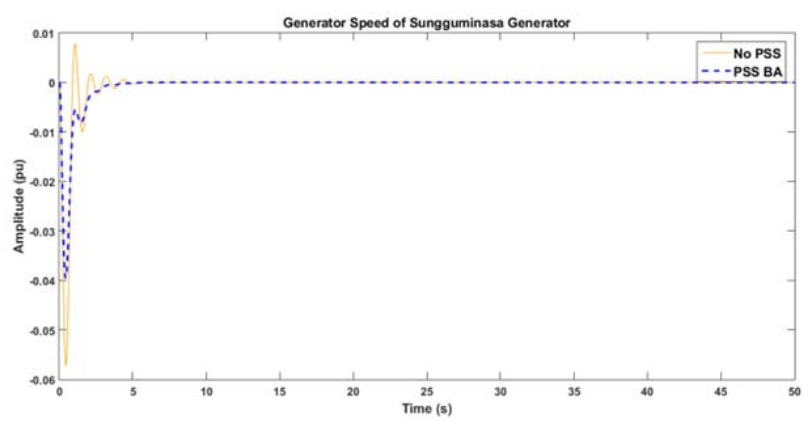

Gambar 14. Deviasi Kecepatan $(\Delta \omega)$ G. Sungguminasa

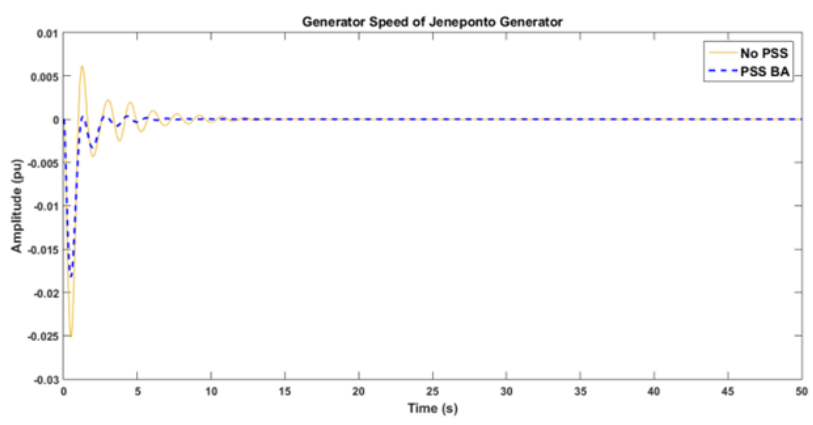


Majalah Ilmiah Teknologi Elektro, Vol. 17, No. 1, Januari - April 2018

DOI: https://doi.org/10.24843/MITE.2018.v17i01.P20

Gambar 15. Deviasi Kecepatan $(\Delta \omega)$ G. Jeneponto

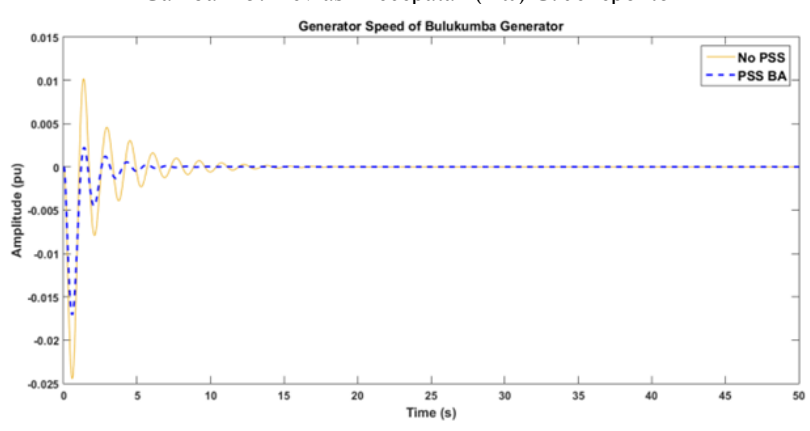

Gambar 16. Deviasi Kecepatan $(\Delta \omega)$ G. Bulukumba

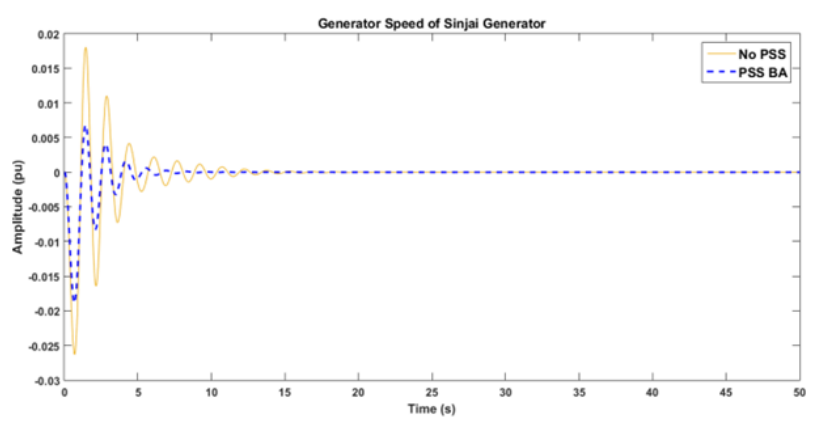

Gambar 17. Deviasi Kecepatan $(\Delta \omega)$ G. Sinjai

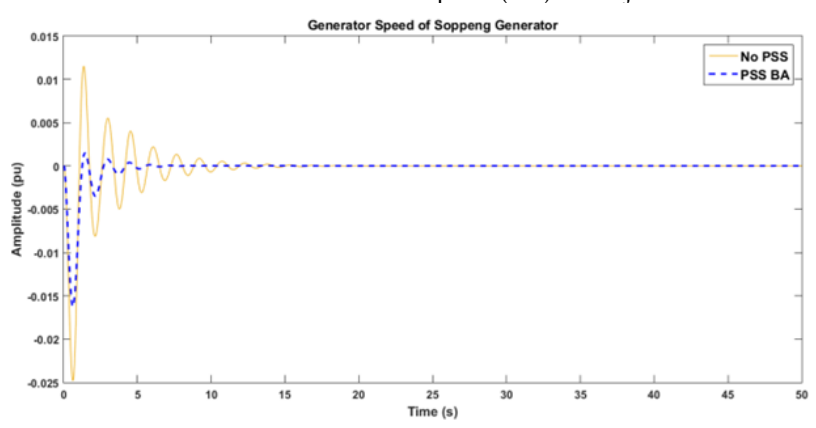

Gambar 18. Deviasi Kecepatan $(\Delta \omega)$ G. Soppeng

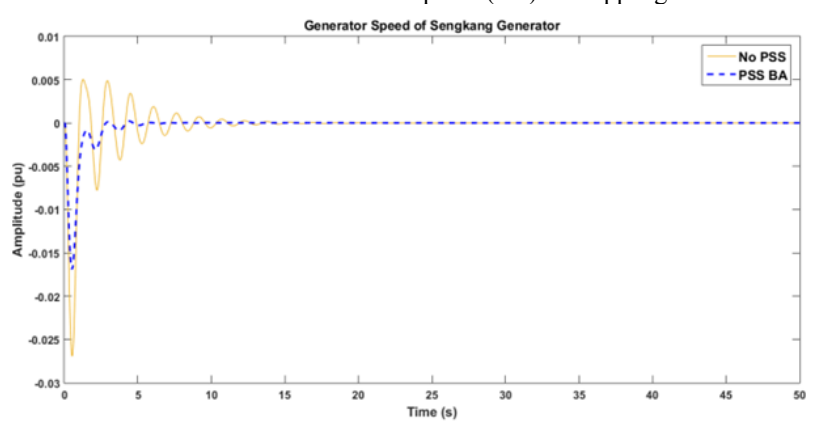

Gambar 19. Deviasi Kecepatan $(\Delta \omega)$ G. Sengkang
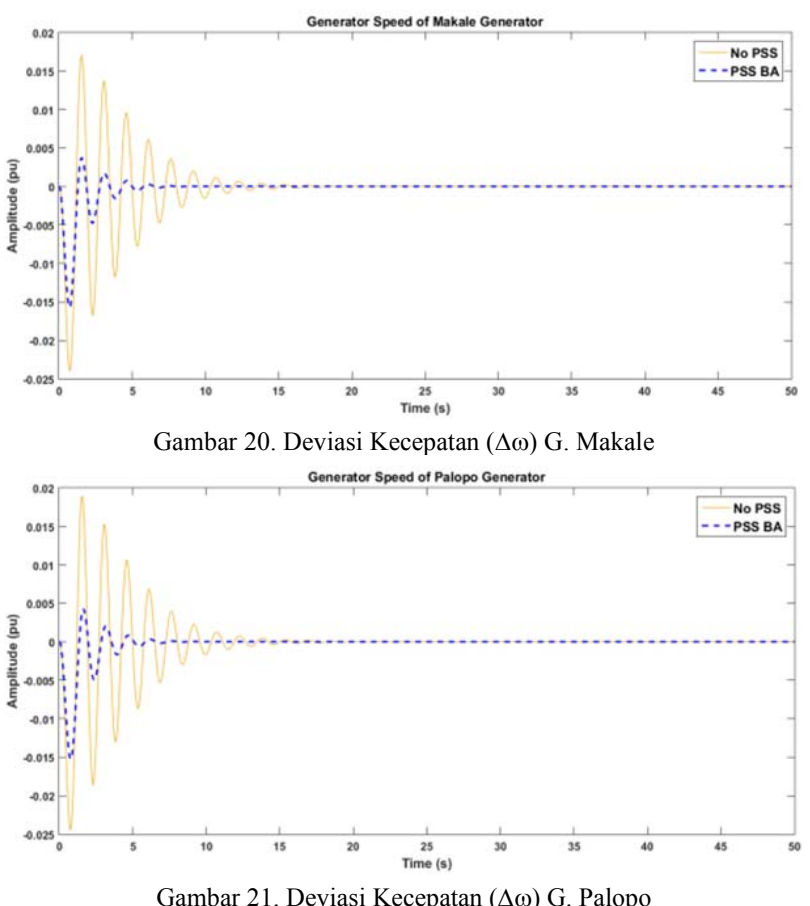

Gambar 21. Deviasi Kecepatan $(\Delta \omega)$ G. Palopo

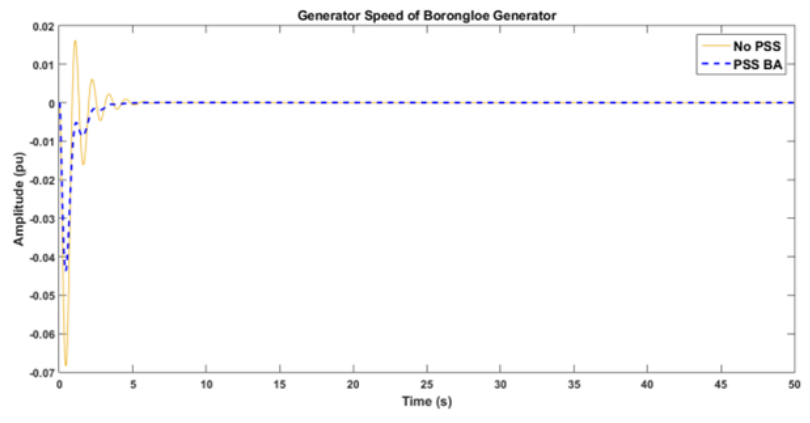

Gambar 22. Deviasi Kecepatan $(\Delta \omega)$ G. Borongloe

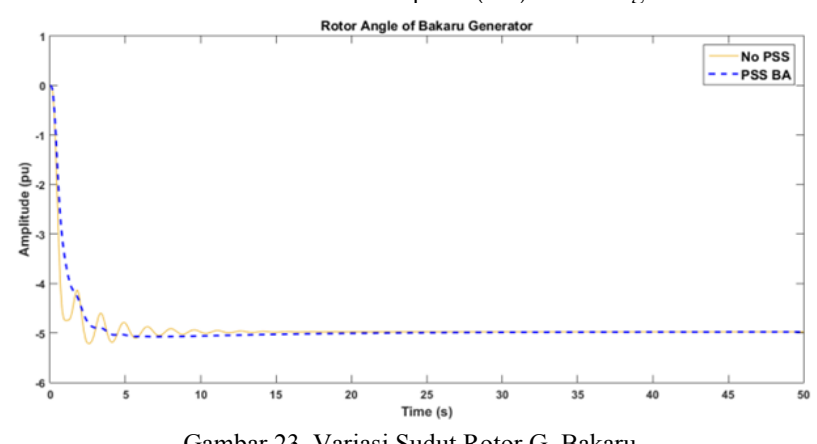

Gambar 23. Variasi Sudut Rotor G. Bakaru

Muhammad Ruswandi Djalal: Desain Optimal Power System...

p-ISSN:1693 - 2951; e-ISSN: 2503-2372 


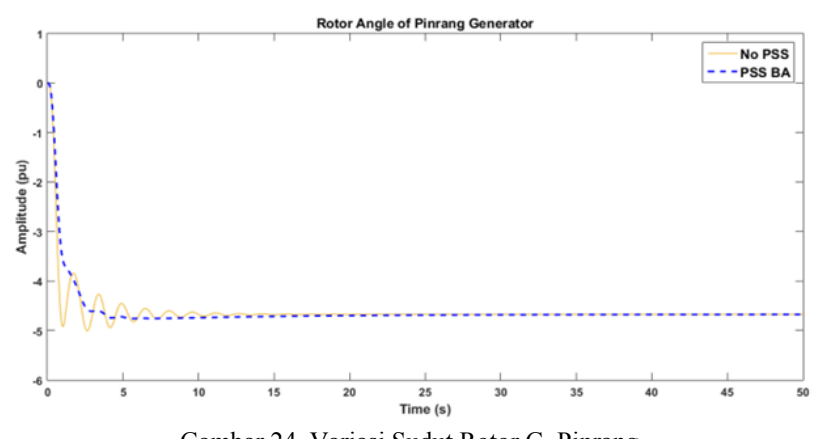

Gambar 24. Variasi Sudut Rotor G. Pinrang

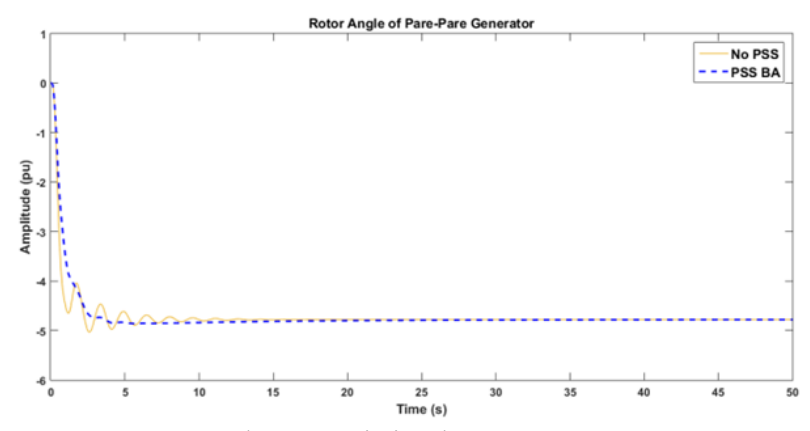

Gambar 25. Variasi Sudut Rotor G. Pare

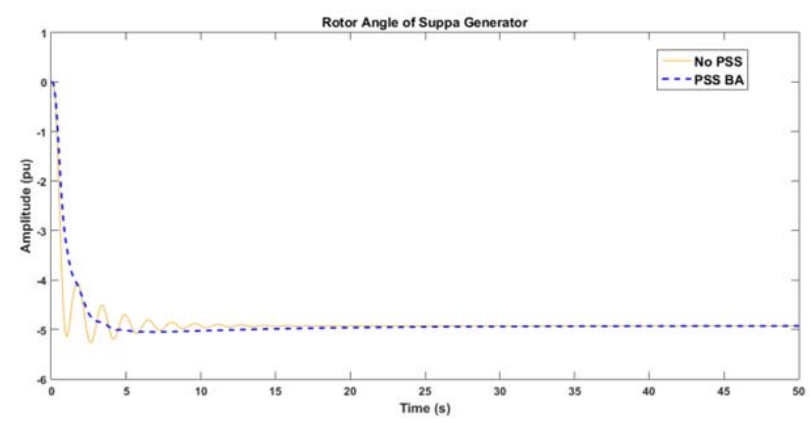

Gambar 26. Variasi Sudut Rotor G. Suppa

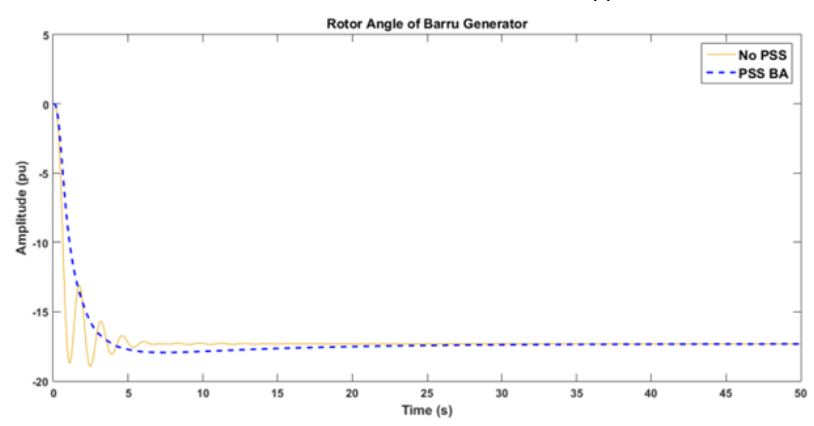

Gambar 27. Variasi Sudut Rotor G. Barru

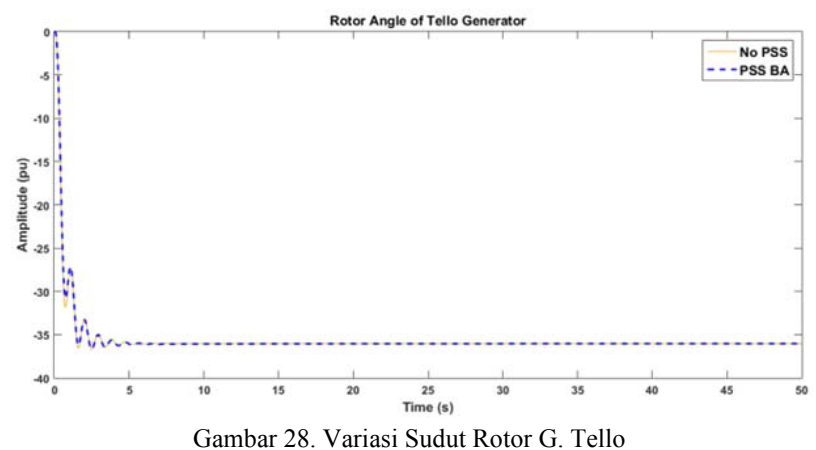

Gambar 28. Variasi Sudut Rotor G. Tello

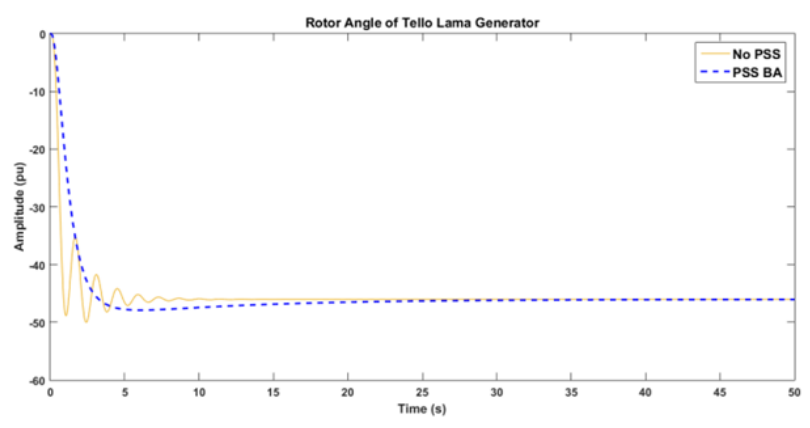

Gambar 29. Variasi Sudut Rotor G. Tello Lama

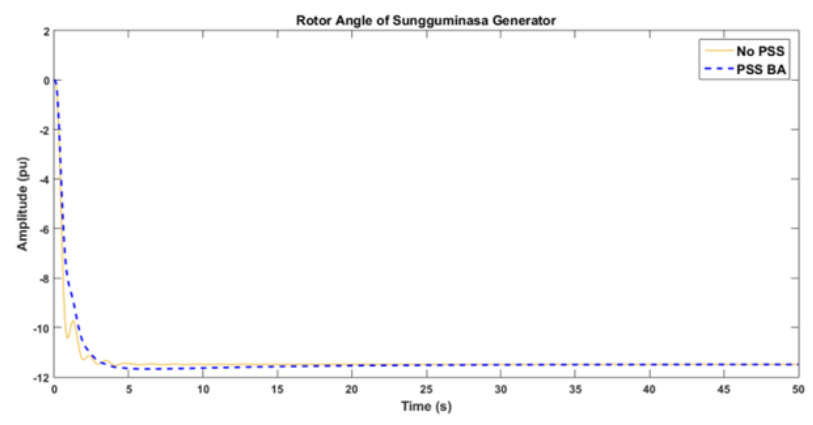

Gambar 30. Variasi Sudut Rotor G. Sungguminasa

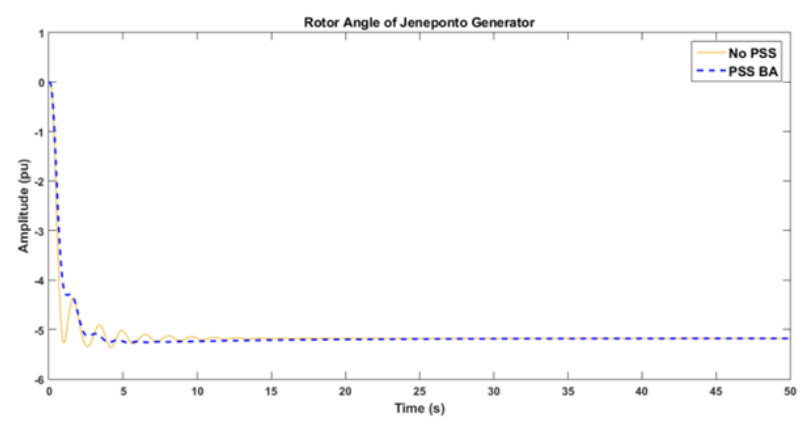

Gambar 31. Variasi Sudut Rotor G. Jeneponto

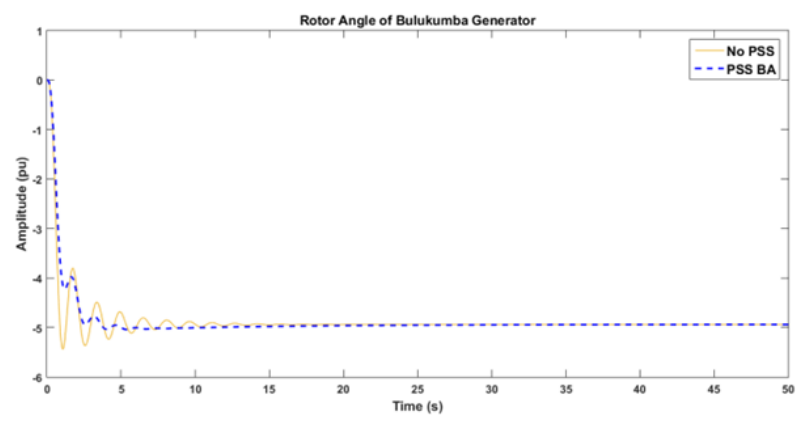

Gambar 32. Variasi Sudut Rotor G. Bulukumba

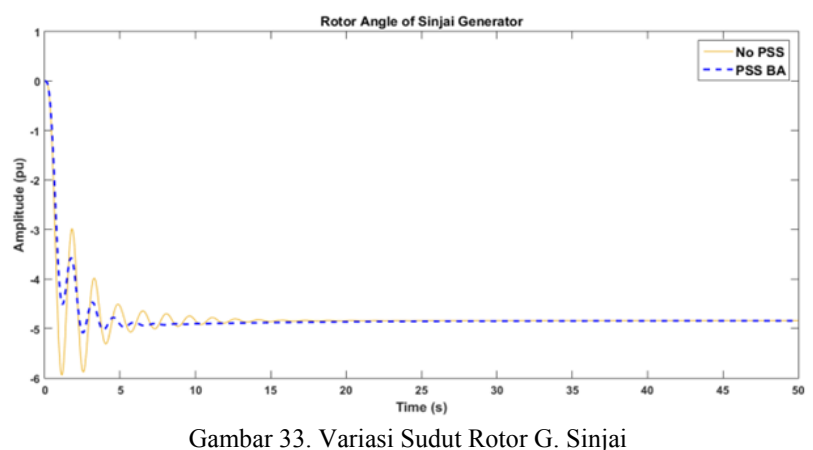

Gambar 33. Variasi Sudut Rotor G. Sinjai 


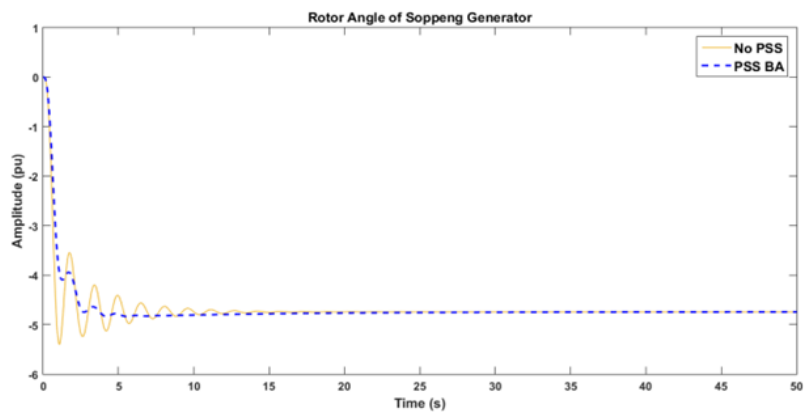

Gambar 34. Variasi Sudut Rotor G. Soppeng

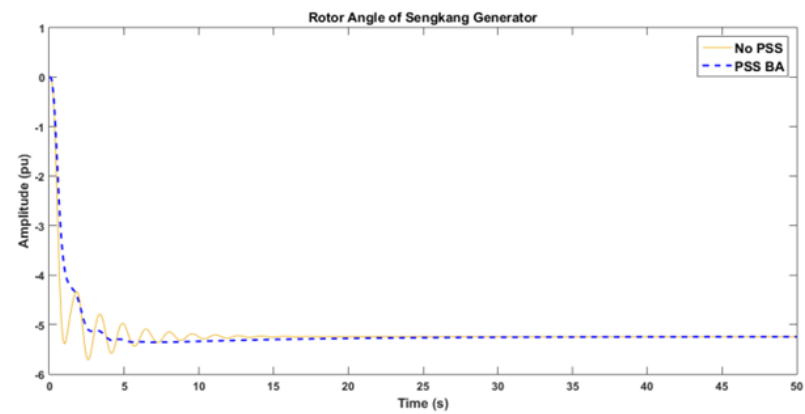

Gambar 35. Variasi Sudut Rotor G.Sengkang

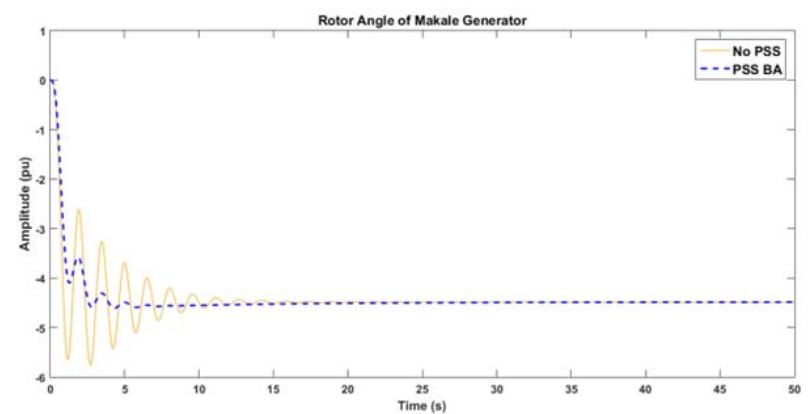

Gambar 36. Variasi Sudut Rotor G. Makale

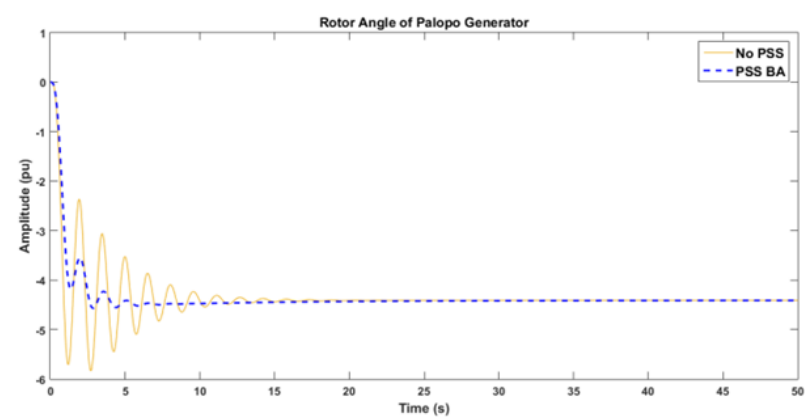

Gambar 37. Variasi Sudut Rotor G. Palopo

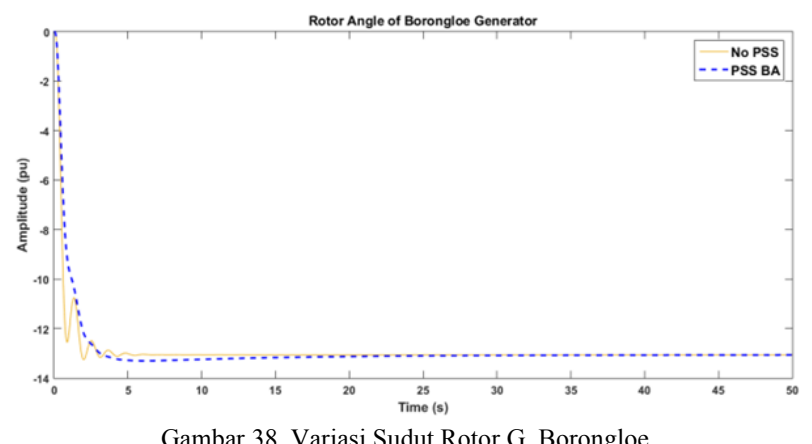

Gambar 38. Variasi Sudut Rotor G. Borongloe

Tabel 5 menunjukkan hasil deviasi overshoot untuk masingmasing system tanpa control dan dengan menggunakan PSS. Di mana dari hasil tersebut, didapatkan deviasi overshoot kecepatan generator yang semakin diredam saat terjadi penambahan beban pada generator Bakaru. Generator Bakaru sendiri memiliki overshoot sebesar -0.02563 sampai 0.004704 pu untuk system tanpa kontrol dan -0.01598 sampai 9.635e-05 pu untuk system dengan PSS.

Untuk analisa respon perubahan kecepatan, perubahan beban yang terjadi menyebabkan $\mathrm{P}_{\mathrm{e}}>\mathrm{P}_{\mathrm{m}}$ sehingga dari grafik untuk kedua studi kasus yang digunakan, respon pertama kecepatan generator adalah kebawah. Sedangkan untuk respon sudut rotor, karena $\mathrm{P}_{\mathrm{e}}>\mathrm{P}_{\mathrm{m}}$, maka rotor akan mengalami perlambatan sehingga respon sudut rotor menjadi negatif.

Pemasangan PSS yang optimal akan memberikan efek ke system yang sangat baik. Dari gambar 6-22 menunjukkan respon Deviasi Kecepatan $(\Delta \omega)$ dan gambar 23-38 sudut rotor masing-masing generator, ketika terjadi gangguan dalam hal ini diberi gangguan pada generator Bakaru, dan dari grafik deviasi kecepatan dapat dilihat besar osilasi overshoot yang terjadi semakin berkurang setelah dipasang PSS, selain itu settling time yang dihasilkan juga akan semakin cepat untuk menuju ke kondisi steady state dengan menggunakan metode yang diusulkan Bat Algorithm dibandingkan dengan sistem tanpa kontrol dan algoritma yang diusulkan juga mempunyai proses optimasi yang cepat dalam menemukan hasil yang optimal.

\section{KESIMPULAN}

Dari hasil analisis dapat disimpulkan, performansi kinerja sistem yang meningkat dengan pemasangan Power System Stabilizer dengan parameter PSS yang optimal dengan menggunakan metode cerdas berbasis algoritma kelelawar.

Hasil analisa menunjukkan deviasi overshoot untuk masing-masing system tanpa control dan dengan menggunakan PSS yang dioptimasi. Di mana dari hasil tersebut, didapatkan deviasi overshoot kecepatan generator yang semakin diredam saat terjadi penambahan beban pada generator Bakaru. Generator Bakaru sendiri memiliki overshoot sebesar -0.02563 sampai 0.004704 pu untuk system tanpa kontrol dan -0.01598 sampai 9.635e-05 pu untuk system dengan PSS. 
Hasil pemasangan PSS yang optimal akan memberikan efek ke system, di mana deviasi kecepatan masing-masing generator saat terjadi gangguan dapat diredam dengan baik.

\section{REFERENSI}

[1] P. A. Mertasana and G. D. Arjana, "PERAMALAN BEBAN LISTRIK JANGKA PENDEK DI BALI MENGGUNAKAN PENDEKATAN ADAPTIVE NEURO-FUZZY INFERENCE SYSTEM (ANFIS)," Majalah Ilmiah Teknologi Elektro, vol. 11.

[2] N. P. S. Utama, "APLIKASI METODE EXSTENDED QUADRATIC INTERIOR POINT (EQIP) UNTUK ECONOMIC DISPATCH PEMBANGKIT TERMAL DI BALI," Majalah Ilmiah Teknologi Elektro, vol. 4, 2005-01-08 2005.

[3] M. R. Djalal, D. Ajiatmo, A. Imran, and I. Robandi, "Desain Optimal Kontroler PID Motor DC Menggunakan Cuckoo Search Algorithm," SENTIA 2015, vol. 7, 2015.

[4] M. R. Djalal, M. A. Haikal, T. M. P. N. U. Pandang, and T. E. I. P. Aceh, "Penyelesaian Aliran Daya 37 Bus Dengan Metode Newton Raphson (Studi Kasus Sistem Interkoneksi $150 \mathrm{kV}$ Sulawesi Selatan)," Jurnal Teknik Mesin SINERGI, vol. 12, pp. 35-49, 2014.

[5] M. R. Djalal, H. Nawir, H. Setiadi, and A. Imran, "An Approach Transient Stability Analysis Using Equivalent Impedance Modified in $150 \mathrm{kV}$ South of Sulawesi System," Journal of Electrical and Electronic Engineering-UMSIDA, vol. 1, pp. 1-7, 2017.

[6] A. Ameli, M. Farrokhifard, A. Ahmadifar, A. Safari, and H. A. Shayanfar, "Optimal tuning of Power System Stabilizers in a multimachine system using firefly algorithm," in 2013 12th International Conference on Environment and Electrical Engineering, 2013, pp. 461-466.

[7] H. Shayeghi, A. Safari, and H. Shayanfar, "Multimachine power system stabilizers design using PSO algorithm."

[8] K. Hongesombut, Y. Mitani, and K. Tsuji, "Power system stabilizer tuning in multimachine power system based on a minimum phase control loop method and genetic algorithm."

[9] M. Jalali, R. Pouaghababa, and M. Nouhi, "Power System Stabilizers Optimization Based on Neural Network using linear Optimal Control."

[10] R. Syahputra and I. Soesanti, "Power System Stabilizer model based on Fuzzy-PSO for improving power system stability," in Advanced Mechatronics, Intelligent Manufacture, and Industrial Automation (ICAMIMIA), 2015 International Conference on, 2015, pp. 121-126.

[11] M. M. Linda and N. K. Nair, "Optimal design of multi-machine power system stabilizer using robust ant colony optimization technique," Transactions of the Institute of Measurement and Control, vol. 34, pp. 829-840, 2012.

[12] B. S. Theja, A. Raviteja, A. Rajasekhar, and A. Abraham, "Coordinated design of power system stabilizer using thyristor controlled series compensator controller: An artificial bee colony approach," in Communication Systems and Network Technologies (CSNT), 2012 International Conference on, 2012, pp. 606-611.

[13] D. Chitara, A. Swarnkar, N. Gupta, K. Niazi, and R. Bansal, "Optimal Tuning of Multimachine Power System Stabilizer using Cuckoo Search Algorithm," IFAC-PapersOnLine, vol. 48, pp. 143148, 2015.

[14] A. B. Muljono, "PENGARUH POWER SYSTEM STABILIZER PADA SISTEM TENAGA LISTRIK DENGAN UNIT PEMBANGKIT TERSEBAR," Majalah Ilmiah Teknologi Elektro, 2012.

[15] I. T. Yuniahastuti, I. Anshori, and I. Robandi, "Load frequency control (LFC) of micro-hydro power plant with Capacitive Energy Storage (CES) using Bat Algorithm (BA)," in 2016 International Seminar on Application for Technology of Information and Communication (ISemantic), 2016, pp. 147-151. 